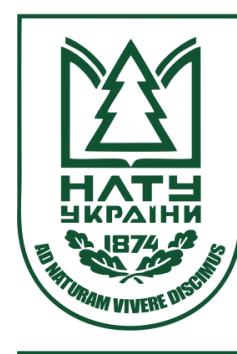

Науковий вісник НЛТУ України Scientific Bulletin of UNFU

http://nv.nltu.edu.ua

https://doi.org/10.15421/40280518

$@ \bowtie$ Correspondence author

Article received 14.05.2018 p.

Article accepted 31.05.2018 p.

M. V. Ruda

УДК 502/504:628.11-047.36

marichkarmv@gmail.com

Н. Ю. Хомко, М. В. Руда

Начіональний університет "Львівська політехніка", м. Львів, Украӥна

\title{
ОЦІНЮВАННЯ ВПЛИВУ "ЛЬВІВВОДОКАНАЛУ" НА ДОВКІЛЛЯ
}

Проаналізовано екологічні проблеми функціонування очисних споруд "Львівводоканалу". Досліджено каналізаційні споруди міста Львова, що складаються з двох технологічних ліній, які розташовані на правому і лівому берегах річки Полтва. Встановлено, що незадовільний стан систем водовідведення і пов'язане з цим забруднення водойм $\epsilon$ однією з головних проблем навколишнього природного середовища України, що становить значний ризик для здоров'я населення. Наявні технічні споруди для відведення та оброблення стічних вод знаходяться на прогресуючій стадії фізичного розпаду. Оскільки провести значну заміну установок найближчим часом $\epsilon$ нереалістично, терміново потрібно розробляти концепції і заходи 3 ремонту наявних установок, які покращують очистку стічних вод і можна їх використати в наступні роки. Проведено дослідження стосовно впливу очисних споруд на територію підприємства, визначено вміст важких металів у осаді первинних відстійників та у грунті, що знаходиться у межі зони впливу цього техногенного об'єкта. Підтверджено, що значні концентрації фенолу, формальдегіду та інших антисептиків спричиняють денатурацію білків протоплазми, а ефір і ацетон руйнують оболонку живих клітин. Встановлено, що на територіях (на захід та на північ від мулових майданчиків) $є$ перевищено норми вмісту важких металів: кадмію, міді, нікелю, свинцю, хрому, цинку. Ці важкі метали належать до I та II класів небезпеки. Не виявлено перевищень ГДК та фонових концентрацій з амонію обмінного, фосфору (рухомі форми), нітратів, сульфатів, хлоридів в об'єднаній пробі грунту на північ від мулових майданчиків.

Ключові слова: мулові майданчики; очисні споруди; каналізаційні відходи; кек; каналізаційний колектор.

Вступ. Вода як косна речовина біосфери і середовище, з якого зародилося і продовжує функціонувати життя, є головною частиною гідросфери. Вода регулює клімат планети, забезпечує господарську та промислову діяльність людей. Обмежені запаси прісної води ще більше скорочуються через їх забруднення. Значну небезпеку становлять стічні води, оскільки велика частина використаної води повертається у водні басейни у вигляді стічних вод.

Проблема утилізації каналізаційних відходів існує у великих і малих містах, розвинених і аграрних країнах. Основними способами позбавлення від них є: затоплення в океані; складування за містом; спалювання (Франція, Канада, Іспанія); використання як добрива, незважаючи на високий вміст важких металів (широкому застосуванню перешкоджають неестетичний вигляд, неприємний запах, небезпечність споживання овочів на удобреному в такий спосіб грунті через наявність у шламі яєць гельмінтів).

Аналіз останніх досліджень і публікацій. Каналізаційні відходи - це шлам, який утворюється у процесі очищення стічних вод на станціях водоочищення. Він збагачений органічними речовинами, біогенними елементами: нітрогеном, фосфором, калієм, кальцієм (Zapolskyi, Saliuk \& Sytnyk, 2001; Biliavskyi, Butchenko \& Navrotskyi, 2002).
Численні мегаполіси світу оточені чорними поясами - муловими майданчиками 3 кеком чи осадом, який залишається після оброблення каналізаційних стічних вод.

Небезпечним є для грунту систематичне використання як добрив осадів стічних вод, забруднених важкими металами. Стічні води шкіряних, годинникових та інструментальних заводів істотно забруднені хромом, підприємства електронної промисловості - кадмієм. 3 продуктами згоряння дизельного палива, мастильними матеріалами в довкілля надходить кадмій і цинк. Свинець потрапляе у грунт внаслідок викидів транспорту, що працює на бензині $з$ домішкою антидетонатора тетраетилсвинцю.

За великих концентрацій важкі метали токсичні для грунтової фауни і рослин, оскільки діють як ферментні отрути, змінюючи метаболізм; впливають на проникність клітинних мембран; заміщують життєво важливі йони (Bobylov, et al., 2014).

Рівень забруднення грунту та просторове поширення важких металів залежить від потужності підприємств-забруднювачів, якості перероблюваної сировини, технології виробництва, ефективності роботи очисних споруд. Постійне надходження важких металів у грунт спричинює формування зон підвищеної екологічної токсичності.

\section{Інформація про авторів:}

Хомко Наталія Юріївна, канд. техн. наук, доцент, кафедра екологічної безпеки та природоохоронної діяльності. Email: nhomko@gmail.com

Руда Марія Віталіївна, асистент, кафедра екологічної безпеки та природоохоронної діяльності. Email: marichkarmv@gmail.com Цитування за ДСтУ: Хомко Н. Ю., Руда М. В. Оцінювання впливу "Львівводоканалу" на довкілля. Науковий вісник НЛТУ України. 2018, т. 28, № 5. C. 83-87.

Citation APA: Khomko, N. Yu., \& Ruda, M. V. (2018). Evaluation of the influence of Lvivvodokanal on the environment. Scientific Bulletin of UNFU, 28(5), 83-87. https://doi.org/10.15421/40280518 
Мета роботи. Проаналізувати екологічні проблеми функціонування очисних споруд "Львівводоканалу". Провести дослідження стосовно впливу очисних споруд на територію підприємства, визначити вміст важких металів у осаді первинних відстійників та у грунті, що знаходиться у межі зони впливу цього техногенного об'єкта.

Результати та обговорення. Місто Львів розташоване вздовж головного вододілу між басейнами Балтійського та Чорного морів. Більша частина міста, зокрема центральна і північна, розташована у верхній частині басейну річки Полтви, котра впадає у річку Західний Буг, яка на території Польщі впадає в Балтійське море. У центральній і північній частині історично склалась загальнопливна система каналізації. У південній частині міста Львова домінує повна роздільна система каналізації. Каналізаційні стоки 3 південної частини міста, яка розташована в басейні Чорного моря, перекачують через вододіл каналізаційні насосні станції та разом із каналізаційними стоками решти міста вони самопливом течуть до міських очисних споруд. Річка Полтва протікає майже через усе місто Львів та через центр міста. Практично всі стоки міста скидались у річку, яка перетворилась у стічну канаву. Тому приблизно з 1890 р. річку почали закривати в колектор. Тому колектор Полтви є основним каналізаційним колектором міста Львова, по якому стоки потрапляють на очисні споруди. Паралельно колектору Полтва прокладено IV каналізаційний колектор. Каналізаційні споруди міста Львова складаються 3 двох технологічних ліній, які розташовані на правому і лівому берегах річки Полтва.

Господарсько-побутові, виробничі та дощові стоки міста по закритому колектору Полтва та IV каналізаційному колектору потрапляють на каналізаційні очисні споруди проектною потужністю 490 тис. м³/добу. Повне найменування очисних споруд - "Очисні споруди каналізації м. Львова".

На очисних спорудах здійснюється механічне і біологічне очищення стоків міста за допомогою піскопасток, первинних відстійників, аеротенків, вторинних відстійників. В аеротенках під дією аеробних бактерій-мінералізаторів відбувається мінералізація розчинених колоїдних органічних речовин способом біологічного окислення. Для діяльності аеробних бактерій-мінералізаторів необхідний кисень, який надходить 3 атмосферним повітрям під певним тиском в об'ємі 6-12 м³ повітря на $1 \mathrm{~m}^{3}$ стічних вод залежно від іiі забруднення.

Очисні споруди каналізації складаються з двох окремих технологічних ліній і розміщені в північно-східній частині міста. Вони займають площу 111 га в долині річки Полтва. Одна технологічна лінія очисних споруд розміщена на правому березі, друга - на лівому березі: майданчик КОС-1, майданчик КОС-2.

Відходи очищення стічних вод, пісок та інші мінеральні домішки видаляються з піскопасток із фракціями понад 0,35 мм на 85-90\%. Ефект освітлення стічних вод повинен досягати 40-50 \%, ущільнення осаду - до 92-94 \%. Вологість осаду з мулових майданчиків не повинна перевищувати 70-80\%. За добу очищується в середньому 436 тис. м ${ }^{3}$ стічних вод і одержується відходів: пісок - 2,01 т; осад - 149 т. Після очищення стічної води є відходи (в середньому): пісок - 740-800 т/рік; сирий осад і мул - 4900-5400 т/рік; сміття 3 решіток 40-50 т/рік.

Осад первинних відстійників подається в цех механічного зневоднення на центрифуги і на мулові майданчики. На біохімічну активність мікроорганізмів активного мулу мають вплив такі чинники: температура, $\mathrm{pH}$, наявність і концентрація токсичних речовин, концентрація кисню і ін. Ефективне очищення стічних вод відбувається за $\mathrm{pH} 6,5-8,5$. Температура стічних вод може змінюватись від 2-5 до $25-35^{\circ} \mathrm{C}$. Мікроорганізми активного мулу мають властивість авторегулювати $\mathrm{pH}$ середовища. Деякі СПАР (сполуки поверхнево активних речовин) важко видаляються біологічним шляхом зі стічних вод і токсичні для бактерій активного мулу, внаслідок чого порушується біологічне очищення річок від забруднень. Це робить воду нездатною для приготування їжі та розведення риби. Забруднення, які містяться у промислових стоках, окислюються у природних водах, що пов'язано із споживанням розчиненого у воді кисню, тому використовують такі показники, як хімічне (ХСК) та біологічне (БСК) споживання кисню, які контролюють працівники санітарної лабораторії підприємства. Багато хімічних елементів та сполук негативно впливають на процеси біохімічного очищення. Значні концентрації фенолу, формальдегіду та інших антисептиків спричиняють денатурацію білків протоплазми, а ефір і ацетон руйнують оболонку живих клітин. Особливо токсичними є солі важких металів, які за ступенем токсичності можна розмістити у ряд: $\mathrm{Sb}>\mathrm{Ag}>\mathrm{Cu}>\mathrm{Hg}>\mathrm{Co}>\mathrm{Ni}>\mathrm{Pb}>\mathrm{Cr}>\mathrm{Cd}>\mathrm{Zn}>\mathrm{Fe}$. Аналіз якості води здійснюють лаборанти ЛМКП "Львівводоканал". У табл. 1 подано вміст важких металів у початковій стічній воді, що надходить на КОС-1 і КОС-2.

Табл. 1. Вміст важких металів у початковій стічній воді

\begin{tabular}{|c|c|c|c|c|}
\hline № & \multirow{2}{*}{$\begin{array}{c}\text { Показник, } \\
\text { з/п }\end{array}$} & \multirow{2}{*}{ ГдК, дм ${ }^{3}$} & & \multicolumn{2}{|c|}{ Концентрація } \\
\cline { 4 - 5 } & & КОС-1 & КОС-2 \\
\hline 1 & хром & $<1,0$ & 0,0 & 0,0 \\
\hline 2 & мідь & $<0,5$ & 0,0 & 0,0 \\
\hline 3 & залізо & $<5,0$ & 4,7 & 4,23 \\
\hline 4 & цинк & $<0,5$ & 1,86 & 1,83 \\
\hline 5 & нікель & $<0,3$ & 0,0 & 0,0 \\
\hline
\end{tabular}

3 табл. 1 видно, що початкова стічна вода містить такі важкі метали, як залізо та цинк. Концентрація заліза у стічній воді не перевищує норми ГДК і становить: КОС-1 - 0,94 ГДК; КОС-2 - 0,85 ГДК. Концентрація цинку перевищує гранично допустиму концентрацію і становить: КОС-1 - 3,72 ГДК; КОС-2 - 3,66 ГДК. У табл. 2 подано вміст важких металів у очищеній стічній воді, що надходить з КОС-1 та КОС-2. 3 таблиці видно, що очищена стічна вода не містить важких металів, окрім заліза, концентрація якого не перевищує ГДК: КОС-1 - 0,1 мг/дм ${ }^{3} ;$ КОС-2 - 0,8 мг/дм ${ }^{3}$ при ГДК $1,0 \mathrm{мг} /$ дм $^{3}$.

Табл. 2. Вміст важких металів у очищеній стічній воді

\begin{tabular}{|c|c|c|c|c|}
\hline № & \multirow{2}{*}{$\begin{array}{c}\text { Показник, } \\
\text { з/п }\end{array}$} & \multirow{2}{*}{ ГдК, мг/дм } & & \multicolumn{2}{|c|}{ Концентрація } \\
\cline { 4 - 5 } & хром & відсутні & КОС-1 & КОС-2 \\
\hline 1 & мідсутні & відсутні \\
\hline 2 & мідь & відсутні & відсутні & відсутні \\
\hline 3 & залізо & 1,00 & 0,9 & 0,8 \\
\hline 4 & цинк & відсутні & відсутні & відсутні \\
\hline 5 & нікель & відсутні & відсутні & відсутні \\
\hline
\end{tabular}

ГОСТ 17.4.1.02-83 (1983) містить класифікацію важких металів за класом небезпечності, у якій враховано їх токсичність, гранично допустиму концентрацію 
у грунті, міграційні властивості. До I класу небезпечності віднесено $\mathrm{As}, \mathrm{Cd}, \mathrm{Hg}, \mathrm{Pb}, \mathrm{Zn}$; до II класу небезпечності - B, Co, Ni, Mo, Cu, Sb, Cr; до III класу небезпечності віднесено V, W, Mn, Sr. Після проведення досліджень 3 визначення вмісту важких металів у мулі $з$ первинних відстійників, а також у грунтах, які знаходяться у зоні впливу "Очисних споруд каналізації м. Львова", було прийнято саме цю класифікацію.

Для оцінювання шкідливої дії важких металів у грунті введено відповідні ГДК: 1) ГДК валового вмісту важких металів в орному шарі грунту та рослинній масі, мг/кг; 2) ГДК рухомих форм важких металів у грунті, мг/кг; 3) кларк важких металів у грунті, мг/кг.

Для загальної характеристики стану грунтів і їх потенційної небезпеки використовують валовий вміст важких металів у грунті, тоді як вміст рухомих форм вказує на рівень їх токсичності. У табл. 3 показано вміст важких металів в осаді первинних відстійників. Відбір проб грунтів, відходів проведено відповідно до вимог ГОСТ 17.4.3.01.-83 "Охрана природы. Почвы. Общие требования к отбору проб" (GOST 17.4.3.01, 1983), ГОСТ 17.4.4.02-84 "Охрана природы. Почвы. Методы отбора и подготовки проб для химического, бактериологического, гельминтологического анализа" (GOST 17.4.4.02, 1984).

Нормований вміст гранично допустимих концентрацій (ГДК) показників у табл. 3 наведено відповідно до ГОСТ 17.4.3.01.-83 "Охрана природы. Почвы. Общие требования к отбору проб", [САНПиН 42-128-4433-87] "Санитарные нормы допустимых концентраций химических веществ в почве" (SANPiN 42-128-4433, 1987),
[ПДК № 3210-85] "Предельно допустимые концентрации химических веществ в почве (ПДК)" (PDK № 3210, 1985). Під час вимірювання застосовано спектрофотометр атомно-абсорбційний С-115-М1.

Табл. 3. Вміст важких металів в осаді первинних відстійників

\begin{tabular}{|c|c|c|c|c|c|}
\hline $\begin{array}{c}\text { № } \\
\text { 3/п }\end{array}$ & Показник & $\begin{array}{c}\text { Одиниця } \\
\text { вимірювання }\end{array}$ & $\begin{array}{c}\text { Валовий } \\
\text { вміст }\end{array}$ & $\begin{array}{c}\text { Рухома } \\
\text { форма }\end{array}$ & $\begin{array}{c}\text { ГДК, } \\
\text { мГ/кг }\end{array}$ \\
\hline 1 & Хром & мг/кг & 16,50 & 0,35 & 6,0 \\
\hline 2 & Мідь & мг/кг & 134,50 & 2,45 & 3,0 \\
\hline 3 & Свинець & мг/кг & 26,81 & 6,10 & 6,0 \\
\hline 4 & Марганець & мГ/кг & 97,05 & 53,75 & $\begin{array}{c}1500 \\
\text { вал. } \\
\text { вміст) }\end{array}$ \\
\hline 5 & Кобальт & мГ/кг & 3,92 & 2,10 & 5,0 \\
\hline 6 & Залізо & мг/кг & 6786,35 & 25,30 & \\
\hline 7 & Кадмій & мГ/кг & 4,06 & 1,05 & 1,0 \\
\hline 8 & Цинк & мг/кг & 389,50 & 151,45 & 23,0 \\
\hline
\end{tabular}

3 табл. 3 видно, що вміст рухомих форм свинцю, що належить до I класу небезпечності, незначно перевищує норму: концентрація рухомих форм $\mathrm{Pb}$ становить 6,1 мг/кг при ГДК=6,0 мг/кг. Вміст кадмію незначно перевищує норму: концентрація рухомих форм Сd становить 1,05 мг/кг при ГДК=1,0 мг/кг. Вміст цинку: концентрація рухомих форм $\mathrm{Zn}$ значно перевищує ГДК і становить 6,6 ГДК.

У табл. 4 наведено вміст важких металів на теритоpiï, що знаходиться біля мулових майданчиків очисних споруд. Вміст важких металів на території біля мулових майданчиків очисних споруд $\epsilon$ показником екологічного стану цієї території.

Табл. 4. Вміст важких металів на території очисних споруд "Львівводоканалу"

\begin{tabular}{|c|c|c|c|c|c|c|c|}
\hline \multirow{2}{*}{$\begin{array}{c}\text { № } \\
\text { проби }\end{array}$} & \multirow{2}{*}{ Місце відбору } & \multirow{2}{*}{$\begin{array}{c}\text { Площа } \\
\text { території, } \\
\text { м }^{2}\end{array}$} & \multirow{2}{*}{$\begin{array}{c}\text { Глибина } \\
\text { відбору, м }\end{array}$} & \multirow{2}{*}{ Показник } & \multirow{2}{*}{$\begin{array}{l}\text { Результат вимі- } \\
\text { рювання, мг/кг }\end{array}$} & \multicolumn{2}{|c|}{ Нормований вміст } \\
\hline & & & & & & гДК & за фоном \\
\hline \multirow{7}{*}{1} & \multirow{7}{*}{$\begin{array}{c}\text { Об'єднана проба } \\
\text { грунту на зх } \\
\text { від мулових } \\
\text { площадок }\end{array}$} & 300 & 0,20 & кадмій (рухомі форми) & 2,15 & - & 0,50 \\
\hline & & 300 & 0,20 & кобальт (рухомі фірми) & 4,13 & 5 & - \\
\hline & & 300 & 0,20 & мідь (рухомі форми) & 4,89 & 3 & - \\
\hline & & 300 & 0,20 & нікель (рухомі форми) & 10,04 & 4 & - \\
\hline & & 300 & 0,20 & свинець (рухомі форми) & 13,17 & 6 & - \\
\hline & & 300 & 0,20 & хром (рухомі форми) & 20,10 & 6 & - \\
\hline & & 300 & 0,20 & цинк (рухомі форми) & 46,12 & 23 & - \\
\hline \multirow{7}{*}{2} & \multirow{7}{*}{$\begin{array}{c}\text { Об'єднана проба } \\
\text { грунту на пн } \\
\text { від мулових } \\
\text { площадок }\end{array}$} & 180 & 0,20 & кадмій (рухомі форми) & 1,84 & - & 0,50 \\
\hline & & 180 & 0.20 & кобальт (рухомі форми) & 3,90 & 5 & - \\
\hline & & 0,20 & 0,20 & мідь (рухомі форми) & 6,52 & 3 & - \\
\hline & & 180,0 & 0,20 & нікель (рухомі форми) & 3,63 & 4 & - \\
\hline & & 180,0 & 0.20 & свинець (рухомі форми) & 16,64 & 6 & - \\
\hline & & 180,0 & 0,20 & хром (рухомі форми) & 10,08 & 6 & - \\
\hline & & 180,0 & 0,20 & цинк (рухомі форми) & 26,12 & 23 & - \\
\hline
\end{tabular}

Лабораторно-аналітичні дослідження важких металів у грунтових зразках проводили на спектрофотометрі атомно-абсорбційному C-115-М1. 3 табл. 4 видно, що на території, що знаходиться на захід від мулових майданчиків, є перевищені норми за вмістом важких металів (див. табл. 4): мідь - 4,89 мг/кг (1,63 ГДК); нікель - 10,04 мг/кг (2,51 ГДК); свинець - 13,17 мг/кг (2,2 ГДК); $\quad$ хром - 20,10 мг/кг (3,35 ГДК); цинк 46,12 мг/кг (2,01 ГДК). Концентрація кадмію становить 2,15 мг/кг, що перевищує фонову концентрацію у 43 рази. Ці важкі метали належать до I та II класу небезпеки.

На території, що знаходиться на північ від мулових майданчиків, виявлено перевищення: кадмію -
1,84 мг/кг (у 3,68 раза більше за фоном); міді 6,52 мг/кг (2,17 ГДК); свинцю - 16,64 мг/кг (2,77ГДК); хрому - 10,08 мг/кг $\quad(1,68$ ГДК); цинку - 26,12 $(1,14$ ГДК). У табл. 5 показано результати фізико-хімічних досліджень грунту, які полягають у визначенні амонію обмінного, фосфору (рухомі форми), нітратів, сульфатів, хлоридів. Під час вимірювання застосовано спектрофотометр атомно-адсорбційний C-15-M1. Нормований вміст ГДК наведено відповідно до (GOST 17.4.3.01, 1983).

3 табл. 5 видно, що перевищень ГДК та фонових концентрацій щодо амонію обмінного, фосфору (рухомі форми), нітратів, сульфатів, хлоридів в об'єднаній пробі грунту на північ від мулових майданчиків не виявлено. 
Табл. 5. Результати фізико-хімічних досліджень об'єднаної проби грунту на Північ від мулових майданчиків

\begin{tabular}{|c|c|c|c|c|c|c|c|}
\hline \multirow{2}{*}{$\begin{array}{l}\text { Номер } \\
\text { проби }\end{array}$} & \multirow{2}{*}{ Місце відбору } & \multirow{2}{*}{$\begin{array}{l}\text { Площа те- } \\
\text { риторії, } \\
\text { м }^{2}\end{array}$} & \multirow{2}{*}{$\begin{array}{l}\text { Глибина } \\
\text { відбору, м }\end{array}$} & \multirow{2}{*}{ Показник } & \multirow{2}{*}{$\begin{array}{c}\text { Результат ви- } \\
\text { мірювання, } \\
\text { мг/кГ }\end{array}$} & \multicolumn{2}{|c|}{ Нормований вміст } \\
\hline & & & & & & ГДК & за фоном \\
\hline 1 & 2 & 3 & 4 & 5 & 6 & 7 & 8 \\
\hline \multirow{5}{*}{1} & \multirow{5}{*}{$\begin{array}{c}\text { Об'єднана проба } \\
\text { грунту на пн від } \\
\text { мулових } \\
\text { майданчиків }\end{array}$} & 300 & 0,20 & $\begin{array}{c}\text { амоній (обмінний) у перерахунку } \\
\text { на азот амонійний } \mathrm{N}\left(\mathrm{NH}^{4+}\right)\end{array}$ & 6,80 & & 7,82 \\
\hline & & 300 & 0,20 & $\begin{array}{c}\text { фосфор (рухомі форми) у перерахунку } \\
\text { на п'ятиоксид фосфору } \mathrm{P}_{2} \mathrm{O}_{5}\end{array}$ & 163.88 & - & 202,69 \\
\hline & & 300 & 0,20 & нітрати (алюмокалієва витяжка) & 71.07 & 130 & - \\
\hline & & 300 & 0,20 & сульфати (водна витяжка) & 150,96 & 160 & - \\
\hline & & 300 & 0,20 & хлориди (водна витяжка) & 24,85 & 24,85 & - \\
\hline \multirow{5}{*}{2} & \multirow{5}{*}{$\begin{array}{c}\text { Фон, об'єднана } \\
\text { проба грунту бі- } \\
\text { ля цеху меха- } \\
\text { нічного зневод- } \\
\text { нення осаду }\end{array}$} & 25 & 0,20 & $\begin{array}{c}\text { амоній (обмінний) у перерахунку на } \\
\text { азот амонійний } \mathrm{N}\left(\mathrm{NH}^{4+}\right)\end{array}$ & 7,82 & - & - \\
\hline & & 180 & 0,20 & $\begin{array}{c}\text { фосфор (рухомі форми) у перерахунку } \\
\text { на п'ятиоксид фосфору } \mathrm{P}_{2} \mathrm{O}_{5}\end{array}$ & 202,69 & - & - \\
\hline & & 0,20 & 0,20 & нітрати (алюмокалієва витяжка) & 88,16 & 130 & - \\
\hline & & 180 & 0,20 & сульфати (водна витяжка) & 112,80 & 160 & - \\
\hline & & 180 & 0,20 & хлориди (водна витяжка) & 24,85 & - & - \\
\hline
\end{tabular}

Висновки. Дослідження показали, що стічна вода, що надходить на КОС-1 та КОС-2 містить такі важкі метали, як залізо та цинк. Концентрація заліза у стічній воді не перевищує норми ГДК і становить: КОС-1 0,94 ГДК; КОС-2 - 0,85 ГДК. Концентрація цинку перевищує гранично допустиму концентрацію і становить: КОС-1 - 3,72 ГДК; КОС-2 - 3,66 ГДК. Очищена стічна вода не містить важких металів, окрім заліза, концентрація якого не перевищує ГДК: КОС-1 - 0,1 мг/дм³ КОС-2 - 0,8 мг/дм ${ }^{3}$ при ГДК - 1,0 мг/дм³.

В осаді первинних відстійників $є$ перевищення норм за цинком, що належить до I класу небезпечності: концентрація рухомих форм $\mathrm{Zn}$ значно перевищує ГДК і становить 6,6 ГДК. Перевищення норм кадмію та свинцю незначне.

Вміст важких металів на території біля мулових майданчиків "Очисних споруд каналізації м. Львова" $\epsilon$ показником екологічного стану цієї території. На територіях, що знаходяться на захід та на північ від мулових майданчиків, є перевищені норми вмісту важких металів: кадмію, міді, нікелю, свинцю, хрому, цинку. Ці важкі метали належать до I та II класів небезпеки.
Не виявлено перевищень ГДК та фонових концентрацій 3 амонію обмінного, фосфору (рухомі форми), нітратів, сульфатів, хлоридів в об'єднаній пробі грунту на північ від мулових майданчиків.

\section{Перелік використаних джерел}

Biliavskyi, H. O., Butchenko, L. I., \& Navrotskyi, V. M. (2002). Osnovy ekolohii: teoriia ta praktykum. Kyiv: Libra. 352 p. [In Ukrainian].

Bobylov, Yu. P., Bryhadyrenko, V. V., Pakhomova, O. Ie. (Ed.), et al. (2014). Ekolohiia. Kharkiv: Folio. 666 p. [In Ukrainian].

GOST 17.4.3.01.-83. Ohrana prirody. Pochvy. Obshhie trebovanija $k$ otboru prob. [In Russian].

GOST 17.4.4.02-84. Ohrana prirody. Pochvy. Metody otbora i podgotovki prob dlja himicheskogo, bakteriologicheskogo, gel'mintologicheskogo analiza. [In Russian].

PDK № 3210-85. Predel'no dopustimye koncentracii himicheskih veshhestv v pochve (PDK). [In Russian].

SANPiN 42-128-4433-87. Sanitarnye normy dopustimyh koncentracij himicheskih veshhestv v pochve. [In Russian].

Zapolskyi, A. K., Saliuk, A. I., \& Sytnyk, K. M. (Ed.). (2001). Osnovy ekolohii. Kyiv: Vyshcha shkola. 358 p. [In Ukrainian].

\section{Н. Ю. Хомко, М. В. Руда}

Национальный университет "Львовская политехника", г. Львов, Украина

\section{ОЦЕНКА ВЛИЯНИЯ "ЛЬВОВВОДОКАНАЛА" НА ОКРУЖАЮЩУЮ СРЕДУ}

Проанализированы экологические проблемы функционирования очистных сооружений "Львовводоканала". Исследованы канализационные сооружения города Львова, состоящие из двух технологических линий, расположенных на правом и левом берегах реки Полтва. Доказано, что неудовлетворительное состояние систем водоотведения и связанное с этим загрязнение водоемов является одной из центральных проблем окружающей природной среды Украины, что представляет значительный риск для здоровья населения. Имеющиеся технические сооружения для отвода и обработки сточных вод находятся на прогрессирующей стадии физического распада. Поскольку провести значительную замену установок в ближайшее время является нереалистичным, срочно нужно разрабатывать концепции и мероприятия по ремонту имеющихся установок, которые улучшают очистку сточных вод и могут быть использованы в последующие годы. Проведено исследование о влиянии очистных сооружений на территорию предприятия, определено содержание тяжелых металлов в осадке первичных отстойников и в почве, которая находится в пределах зоны влияния данного техногенного объекта. Подтверждено, что значительные концентрации фенола, формальдегида и других антисептиков вызывают денатурацию белков протоплазмы, а эфир и ацетон разрушают оболочку живых клеток. Установлено, что на территориях, которые находятся на запад и на север от иловых площадок, превышена норма содержания тяжелых металлов: кадмия, меди, никеля, свинца, хрома, цинка. Эти тяжелые металлы относятся к I и II классам опасности. Превышений ПДК и фоновых концентраций по аммонию обменному, фосфору (подвижные формы), нитратах, сульфатах, хлоридах в объединенной пробе почвы к северу от иловых площадок не обнаружено.

Ключевые слова: иловые площадки; очистные сооружения; канализационные отходы; кек; канализационный коллектор. 
N. Yu. Khomko, M. V. Ruda

Lviv Polytechnic National University, Lviv, Ukraine

EVALUATION OF THE INFLUENCE OF LVIVVODOKANAL ON THE ENVIRONMENT

The environmental problems of functioning of Lvivvodokanal treatment facilities are analyzed. Sewage structures of the city of Lviv, consisting of two technological lines, located on the right and left banks of the Poltva River were investigated. The level of soil contamination and the spatial distribution of heavy metals depends on the capacity of polluting enterprises, the quality of recycled raw materials, production technology, and the efficiency of treatment facilities. The constant flow of heavy metals into the soil leads to the formation of areas of increased environmental toxicity. Numerous metropolises of the world are surrounded by black belts sludge sites with a cake or sediment that remains after sewage treatment. It has been revealed that sewage treatment plants consist of two separate technological lines and are located in the north-eastern part of the city. The research was carried out on the impact of treatment facilities on the territory of the enterprise. The content of heavy metals in the sediment of primary sediment and in the soil located at the boundary of the zone of influence of this man-made object was determined. It is confirmed that significant concentrations of phenol, formaldehyde and other antiseptics cause denaturation of proteins of protoplasm, and ether and acetone destroy the shell of living cells. Particularly toxic are salts of heavy metals, which according to the degree of toxicity can be placed in a row: $\mathrm{Sb}>\mathrm{Ag}>\mathrm{Cu}>\mathrm{Hg}>\mathrm{Co}>\mathrm{Ni}>\mathrm{Pb}>\mathrm{Cr}>\mathrm{Cd}>\mathrm{Zn}>\mathrm{Fe}$. It has been defined that in the territories located to the West and North from the sludge sites the norms of the content of heavy metals such as cadmium, copper, nickel, lead, chromium, and zinc are exceeded. These heavy metals belong to the 1st and 2nd grade of danger. Excessive MAC and background concentrations of ammonium in exchange, phosphorus (moving forms), nitrates, sulphates, and chlorides in the combined soil sample to the North from the sludge sites were not found. It has been investigated that significant concentrations of phenol, formaldehyde and other antiseptics cause denaturation of protoplasm proteins, and ether and acetone destroy the shell of living cells.

Keywords: mud grounds; treatment plant; sewage waste; sewage collector. 